\title{
Estimasi Kedalaman dan Perubahan Volume Sumber Tekanan Gunung Merapi Berdasarkan Pengamatan Data Tiltmeter
}

\author{
Okinawa Rikenata Aida Islamiyah, Agus Budi Santoso, dan Eko Minarto \\ Departemen Fisika, Fakultas Ilmu Alam, Institut Teknologi Sepuluh Nopember, Kampus ITS- \\ Sukolilo, Surabaya 60111, Jawa Timur \\ Balai Penyelidikan dan Pengembangan Teknologi Kebencanaan Geologi (BPPTKG), Kota Yogyakarta \\ 55166, Daerah Istimewa Yogyakarta \\ e-mail: e.minarto@googlemail.com
}

\begin{abstract}
Abstrak-Gunung Merapi merupakan salah satu gunungapi yang memiliki aktivitas vulkanisme tinggi. Untuk meminimalisir dampak erupsi Gunung Merapi diperlukan suatu kegiatan berupa monitoring aktivitas Gunung Merapi. Dalam penelitian ini dilakukan monitoring aktivitas Gunung Merapi menggunakan tiltmeter selama kurun periode 1 September-30 Desember 2017 untuk mendapatkan estimasi kedalaman dan perubahan volume dari sumber tekanan gunung. Data bacaan tiltmeter kemudian diimpor ke perangkat lunak Matlab 2017a. Kemudian dilakukan resampling, pemberian filter, serta regresi linier sehingga didapatkan plot vektor tiltmeter dan pemodelan Mogi. Dari hasil penelitian ini didapatkan estimasi kedalaman sumber tekanan Gunung Merapi adalah berkisar pada kedalaman $2042,450 \mathrm{~m}$ hingga $4533,337 \mathrm{~m}$ di bawah kawah gunung. Dan perubahan volume sumber tekanan berkisar pada $23075,386 \mathrm{~m}^{3}$ hingga 385147,190 $\mathbf{m}^{3}$. Dari hasil pemodelan tersebut diketahui bahwa Gunungapi Merapi tidak menunjukkan aktivitas vulkanis yang signifikan.
\end{abstract}

Kata Kunci-Merapi, Mogi, Monitoring, Tiltmeter.

\section{PENDAHULUAN}

$\mathrm{M}$ ENURUT Pusat Vulkanologi dan Mitigasi Bencana Geologi, terdapat 129 gunungapi aktif di Indonesia. Adanya gunungapi di Indonesia tentu menimbulkan dampak baik dan dampak negatif. Salah satu dampak negatif dari gunungapi ini adalah bahaya dari letusan gunungapi yang mengandung material magma yang membahayakan bagi masyarakat di sekitar gunung. Salah satu gunungapi di Indonesia yang masih aktif hingga sekarang adalah Gunung Merapi yang terletak di Yogyakarta. Gunung Merapi merupakan salah satu gunungapi yang memiliki aktivitas vulkanisme tinggi. Aktivitas vulkanisme gunung berkaitan dengan dapur magma yang menyebabkan adanya perubahan bentuk badan gunung berupa pengembangan (inflation) atau pengempisan (deflation). Perubahan permukaan gunung dijadikan sebagai indikator dalam memperkirakan terjadinya erupsi. Untuk meminimalisir dampak erupsi Gunung Merapi berupa adanya korban jiwa dan kerugian materiil yang besar diperlukan suatu kegiatan berupa monitoring aktivitas Gunung Merapi dimana monitoring ini menggunakan instrumen tiltmeter yang mengukur perubahan kemiringan pada struktur permukaan Gunung Merapi.

Vulkanologi merupakan sebuah studi mengenai kenaikan magma (batuan meleleh) menuju mantel dan kerak Bumi dan erupsinya pada permukaan Bumi. Vulkanologi menguraikan tentang evolusi dari magma dan pergerakannya serta erupsinya [1]. Gunungapi merupakan sebuah rekahan dalam kerak bumi yang menjadi tempat keluarnya magma, gas, atau cairan lainnya ke permukaan bumi. Bahan utama pembentuk gunungapi adalah magma, yaitu suatu fluida kompleks yang terdiri dari batuan cair dengan suhu yang sangat tinggi yang berasal dari dalam perut bumi yang kemudian magma yang muncul ke permukaan bumi ini disebut sebagai lava [2].

Proses terbentuknya gunungapi umumnya terjadi pada daerah yang berada pada zona subduksi. Pada zona ini akan terbentuk retakan yang akan menjadi jalan keluar magma ke permukaan bumi. Magma yang muncul ke permukaan bumi akan mengalami diferensiasi akibat adanya perbedaan tekanan saat naik menuju puncak gunung. Perbedaan tekanan ini menyebabkan sifat fisik magma akan berubah sehingga berpengaruh tipe struktur gunungapi dan jenis letusannya [3].

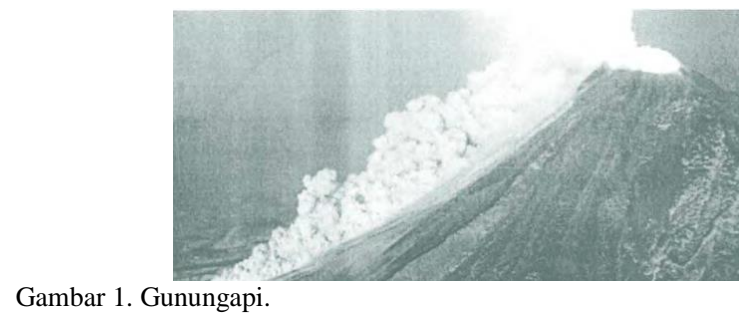

Magma yang mengalami peningkatan berinteraksi dengan batuan dan fluida di sekitarnya. Interaksi ini menimbulkan adanya rekahan batuan sehingga menjadi jalur baru bagi magma untuk mengalir dan terkumpul pada suatu reservoir bawah tanah. Pembentukan jalur baru dan perubahan tekanan di dalam reservoir menimbulkan adanya tekanan sehingga merusak batuan di sekitarnya. Kerusakan batuan ini menimbulkan adanya perubahan bentuk dari gunung dan perubahan inilah yang disebut sebagai deformasi [4].

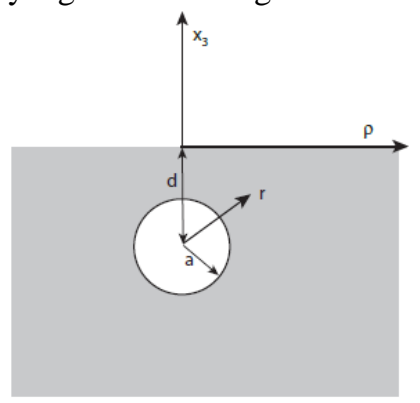

Gambar 2. Geometri Sumber Tekanan pada Half-space Infinit. 


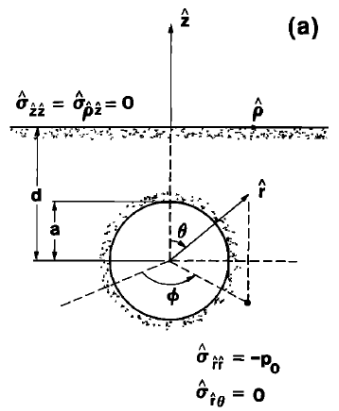

Gambar 3. Geometri Sumber Tekanan dengan Syarat Batas.

Solusi klasik untuk deformasi permukaan Bumi yang disebabkan oleh adanya aktivitas perubahan tekanan pada sumber magma pertama kali digagas oleh Anderson (1936) [5]dan Mogi (1958) [6] dalam bentuk geometri titik sumber pada half-space infinit seperti pada gambar 3 dan 4 . Model Mogi adalah model yang paling banyak digunakan karena merupakan model yang sederhana. Model Mogi mengasumsikan material elastis dengan permukaan bebas dan tidak ada tarikan pada permukaan. Pada model Mogi, diasumsikan bahwa lapisan bawah permukaan adalah linear, elastis, isotropis, dan homogen [7].

$$
\begin{aligned}
& u_{z}=\frac{(1-v) \Delta V}{\pi} \frac{d}{\left(\rho^{2}+d^{2}\right)^{3 / 2}} \\
& u_{\rho}=\frac{(1-v) \Delta V}{\pi} \frac{\rho}{\left(\rho^{2}+d^{2}\right)^{3 / 2}}
\end{aligned}
$$

Kedua persamaan diatas dikenal sebagai model Mogi, yaitu suatu pendekatan dalam permasalahan bola bertekanan pada half-space [8].

Model sumber simetris radial sesuai dengan simetri umum dari pola deformasi yang terekam dalam data tilt. Diasumsikan deformasi permukaan terukur dihasilkan dari perubahan tekanan di dalam ruang magma pada permukaan elastis homogen. Perilaku sumber tekanan dapat dihitung menggunakan kemiringan tanah radial atau radial ground tilt, $\theta_{r}$, yang didapatkan dari turunan perpindahan,

$$
\theta_{r}=\frac{3(1-v) \Delta V}{\pi} \frac{\rho d}{\left(\rho^{2}+d^{2}\right)^{5 / 2}}
$$

Dimana:

$v \quad=$ Rasio Poisson $(v=0.25)$

$\Delta V=$ Perubahan volume pada ruang magma

$\rho=$ Jarak antara sumber dengan stasiun pengamatan

$d \quad=$ Kedalaman Sumber

Positif menunjukkan adanya kenaikan tekanan sumber magma atau volume [9].

Tiltmeter adalah pengamat deformasi yang menyediakan data dalam resolusi mikroradian secara mendekati real-time, dapat beroperasi pada segala macam kondisi, dan dapat diletakkan pada daerah yang sulit dijangkau atau terlalu berbahaya untuk dilakukan penelitian secara berkala. Data deformasi telemeter menyediakan rekaman yang hampir kontinyu untuk mendeteksi adanya perubahan pada gunungapi yang mungkin dapat terjadi dalam kerangka waktu yang singkat dibandingkan dengan pengamatan geodetik standar seperti EDM atau pengukuran Leveling. Tiltmeter sangat sensitif terhadap perubahan temperatur sehingga perlu ditanam dalam kedalaman 1-2 meter dengan tujuan agar instrumen terisolasi dari perubahan temperatur yang signifikan. Tiltmeter terdiri dari tiga komponen utama yaitu pelat tiltmeter, portable tiltmeter, dan readout unit [10].

\section{URAIAN PENELITIAN}

\section{A. Lokasi Penelitian}

Lokasi penelitian terletak pada kawasan Gunung Merapi dengan lokasi secara geografis terletak pada koordinat 07032'30" - 07052'30" LS dan $110^{0} 15^{\prime} 00^{\prime \prime}$ - 110³7'30” BT. Ditinjau secara administratif, Gunung Merapi terletak pada perbatasan empat kabupaten, yaitu Kabupaten Sleman yang terletak di Propinsi Daerah Istimewa Yogyakarta, Kabupaten Magelang, Boyolali, dan Klaten yang terletak di Propinsi Jawa Tengah. Gunung Merapi memiliki ketinggian 2978 m dpl dengan diameter sebesar $28 \mathrm{~km}$, luas sebesar $300-400 \mathrm{~km}^{2}$ serta volume $\pm 150 \mathrm{~km}^{3}$.

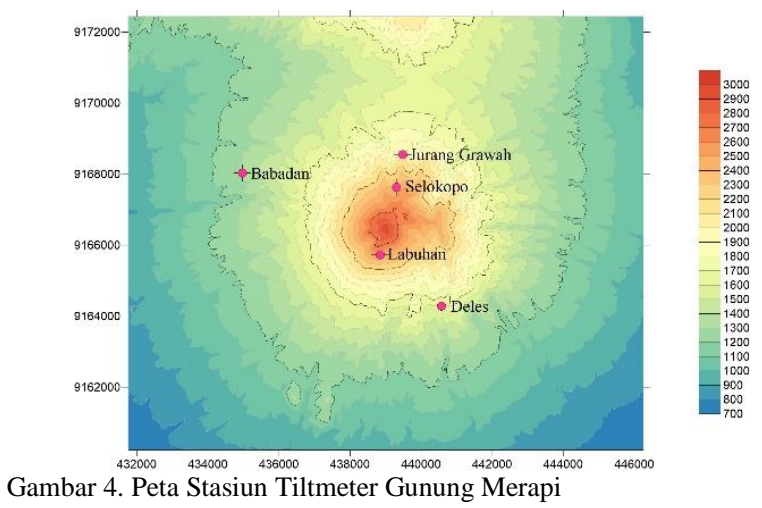

\section{B. Geologi Regional Gunung Merapi}

Gunung Merapi tumbuh di atas titik potong antara kelurusan vulkanik Ungaran-Telomoyo-Merbabu-Merapi dan kelurusan vulkanik Lawu-Merapi-Sumbing-SindoroSlamet. Kelurusan vulkanik Ungaran-Merapi tersebut merupakan sesar mendatar yang berbentuk konkaf hingga sampai ke barat, dan berangsur-angsur berkembang kegiatan vulkanisnya sepanjang sesar mendatar dari arah utara ke selatan. Dapat diurut dari utara yaitu Ungaran Tua berumur Pleistosen dan berakhir di selatan yaitu di Gunung Merapi yang sangat aktif hingga saat ini. Kadang disebutkan bahwa Gunung Merapi terletak pada perpotongan dua sesar kwarter yaitu Sesar Semarang yang berorientasi utara-selatan dan Sesar Solo yang berorientasi barat-timur [11].

Kerucut puncak Merapi yang sering disebut sebagai Gunung Anyar merupakan bagian Merapi yang paling muda. Semua aktivitas Merapi terpusat pada puncak kerucut ini. Kawah utama Merapi saat ini berupa bukaan berbentuk tapal kuda yang mengarah ke barat-baratdaya. Morfologi kawah ini terbentuk sesudah letusan tahun 1961. Secara umum, dataran puncak Merapi tersusun dari kubah-kubah lava yang tidak terlongsorkan. Beberapa area di dataran pucak Merapi di luar kawah utama mengeluarkan banyak uap vulkanik yaitu di area Gendol dan Woro, bagian tenggara dataran puncak [11].

\section{Data Penelitian}

Data yang digunakan pada penelitian ini adalah data tilt hasil pemantauan online pada kantor BPPTKG. Stasiun pengamatan yang digunakan adalah sebanyak 4 stasiun yaitu Labuhan, Jurang Grawah, Selokopo, dan Babadan yang terletak di sekitar Gunung Merapi. Didapatkan data tilt dalam format .CSV dari masing-masing stasiun pengamatan. Rentang waktu dari data yang digunakan dalam penelitian yaitu dalam kurun waktu 4 bulan yaitu 1 September 2017 hingga 30 Desember 2017. 


\section{Prosedur Penelitian}

Proses pengolahan data dilakukan untuk mengetahui estimasi kedalaman dan volume dari sumber tekanan. Pengumpulan data adalah tahap awal dalam mempersiapkan data yang akan diolah. Dalam hal ini data tilt didapatkan dari stasiun pengamatan tiltmeter milik kantor BPPTKG. Data tilt dalam format .CSV diimpor ke perangkat lunak Matlab $2017 a$ serta pemberian filter. Data tilt yang diperoleh berupa pengamatan tiap menit sehingga dilakukan resampling data menjadi 1 hari.

Data tilt yang telah diresampling kemudian dicari regresi liniernya serta dilakukan pencarian ketidakpastian dari regresi linier tersebut. Langkah selanjutnya adalah menghitung jarak masing-masing stasiun pengamatan dari puncak Gunung Merapi. Setelah mendapatkan nilai jarak, dilakukan perhitungan nilai amplitudo. Kemudian pembuatan plot arah vektor tiltmeter tiap stasiun serta plot jarak terhadap amplitudo tiap stasiun. Pada tahap estimasi kedalaman dan volume sumber tekanan Gunung Merapi, dilakukan dengan cara pemodelan menggunakan metode inversi non linear least-square.

\section{E. Diagram Alir Penelitian}

Berikut ini adalah diagram alir penelitian.

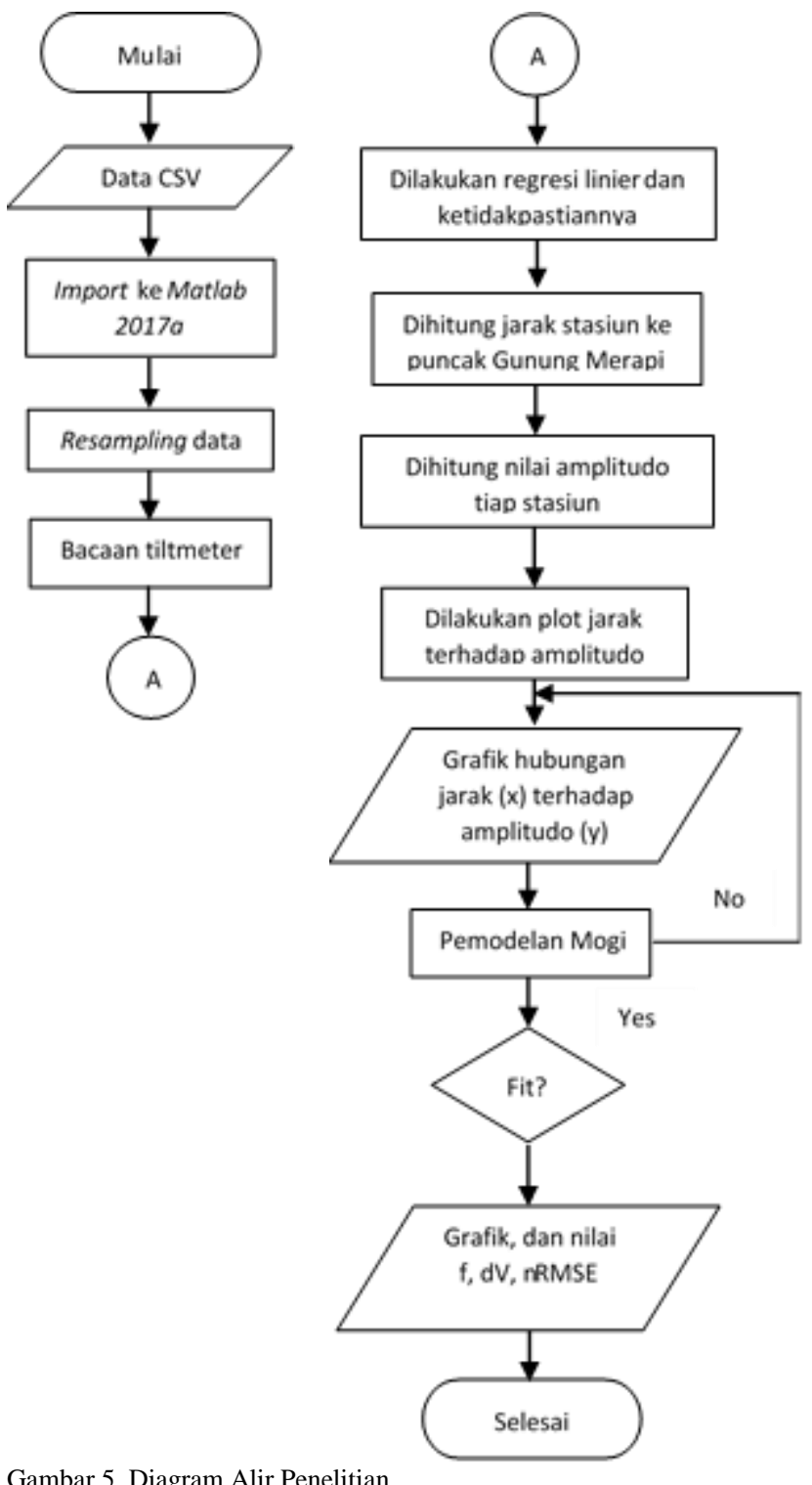

\section{HASIL DAN PEMBAHASAN}

\section{A. Hasil}

Tiltmeter digunakan sebagai instrumen pengukur perubahan permukaan. Tiltmeter memiliki tiga komponen, yaitu komponen radial (sumbu Y), komponen tangensial (sumbu X), serta komponen bacaan temperatur. Pengolahan data dilakukan untuk mendapatkan arah dan besar vektor tiltmeter dari masing-masing stasiun tiltmeter serta estimasi kedalaman dan volume sumber tekanan Gunung Merapi pada kurun waktu 1 September hingga 30 Desember 2017 yang dibagi menjadi 8 periode pengamatan. Pengolahan data tiltmeter ini menghasilkan plot vektor tiltmeter beserta error ellipsnya serta plot jarak terhadap amplitudo tiap stasiun. Plot jarak terhadap amplitudo kemudian digunakan dalam estimasi kedalaman dan volume sumber tekanan menggunakan model Mogi. Berikut ini adalah contoh tampilan plot pemodelan Mogi.

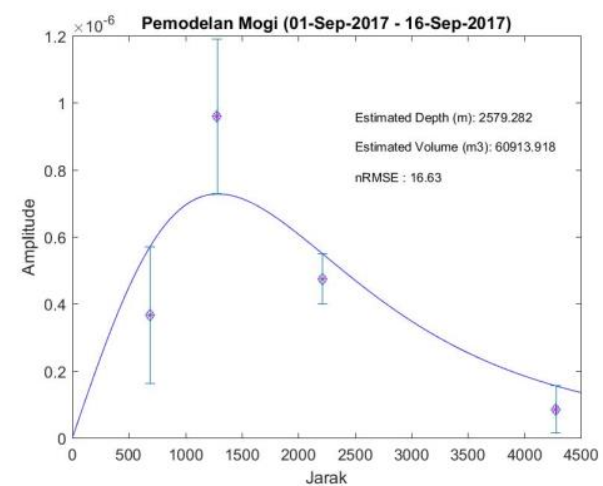

Gambar 6. Plot Pemodelan Mogi Periode Pengamatan 1-16 September 2017.

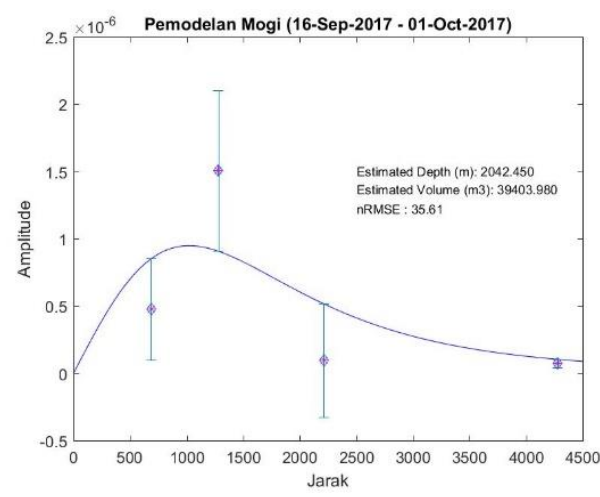

Gambar 7. Plot Pemodelan Mogi Periode Pengamatan 16 September-1 Oktober 2017.

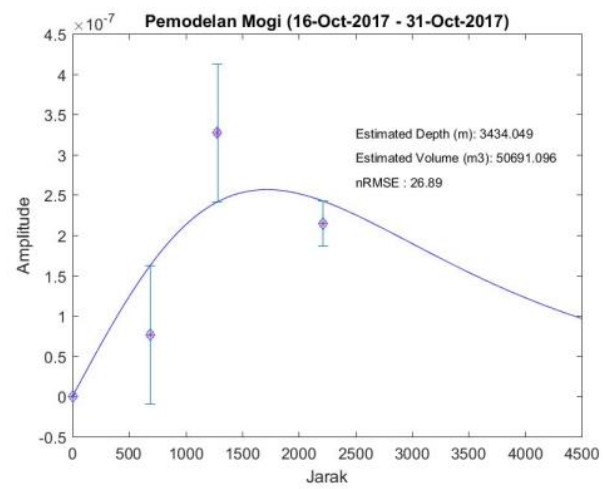

Gambar 8. Plot Pemodelan Mogi Periode Pengamatan 16-31 Oktober 2017 


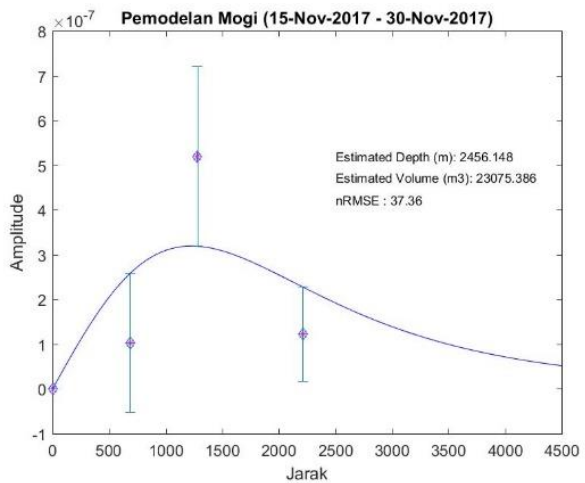

Gambar 9. Plot Pemodelan Mogi Periode Pengamatan 15-30 Nopember 2017.

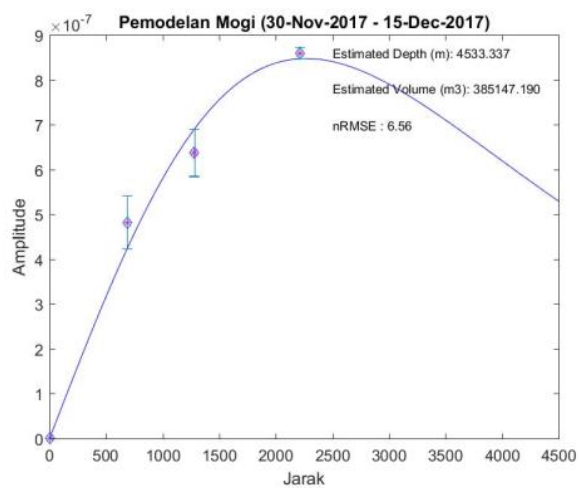

Gambar 10. Plot Pemodelan Mogi Periode Pengamatan 30 Nopember-15 Desember 2017.

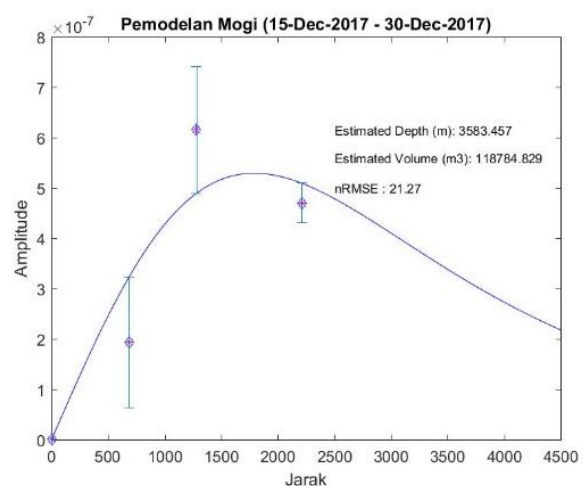

Gambar 11. Plot Pemodelan Mogi Periode Pengamatan 15-30 Desember 2017.

Dari hasil plot pemodelan Mogi yang telah diperoleh, nilai kedalaman, volume, beserta RMSE yang telah dinormalisasi disajikan dalam tabel berikut.

Tabel 1.

Hasil Pemodelan Sumber Tekanan

\begin{tabular}{|c|c|c|c|c|}
\hline No & $\begin{array}{c}\text { Periode } \\
\text { Pengamatan }\end{array}$ & $\begin{array}{l}\text { Kedalaman } \\
\text { (m) }\end{array}$ & $\begin{array}{c}\text { Perubahan } \\
\text { Volume } \\
\left(\mathrm{m}^{3}\right) \\
\end{array}$ & $\begin{array}{c}\text { nRMSE } \\
(\%)\end{array}$ \\
\hline 1. & $\begin{array}{c}\text { 1-16 September } \\
2017\end{array}$ & 2579,282 & 60913.918 & 16.63 \\
\hline 2. & $\begin{array}{l}16 \text { September - } \\
1 \text { Oktober } 2017\end{array}$ & 2042,450 & 39403,980 & 35,61 \\
\hline 3. & $\begin{array}{c}16-31 \\
\text { Oktober } 2017 \\
15-30\end{array}$ & 3434,049 & 50691,096 & 26,89 \\
\hline 4. & $\begin{array}{c}\text { Nopember } \\
2017\end{array}$ & 2456,148 & 23075,386 & 37,36 \\
\hline 5. & $\begin{array}{c}30 \text { Nopember - } \\
15 \text { Desember } \\
2017\end{array}$ & 4533,337 & 385147,190 & 6,56 \\
\hline 6. & $\begin{array}{c}15-30 \\
\text { Desember } 2017\end{array}$ & 3583,457 & 118784,829 & 21,27 \\
\hline
\end{tabular}

\section{B. Pembahasan}

Deformasi didefinisikan sebagai perubahan bentuk pada permukaan tubuh gunungapi. Perubahan ini dapat berupa inflasi (pengembangan) ataupun deflasi (pengempisan). Deformasi terjadi pada batuan yang bertujuan untuk mengimbangi desakan magma. Dari regresi linier didapatkan nilai gradien dari komponen $\mathrm{N}$ dan E serta ketidakpastiannya. Vektor tiltmeter memberikan kita gambaran mengenai deformasi gunungapi beserta orientasi arahnya. Kantung magma diasumsikan berbentuk menyerupai bola. Pada dasarnya kantung magma ini berisi batuan meleleh yang berada pada tekanan yang sangat tinggi. Tekanan pada kantung magma akan menyebar ke segala arah hingga menyebabkan batuan di sekitarnya mengalami retak atau pecah. Retak atau pecahnya batuan ini menyebabkan adanya jalur bagi magma untuk bergerak ke atas. Keretakan batuan ini juga menyebabkan adanya perubahan bentuk gunungapi atau yang disebut sebagai deformasi.

Nilai error disajikan dalam bentuk RMSE yang dinormalisasi. Penggunaan RMSE masih memberikan angka yang cukup susah dalam penggambaran error pemodelan sehingga normalisasi pada nilai RMSE bertujuan untuk mendapatkan angka dengan ukuran yang lebih kecil agar mempermudah dalam mengetahui seberapa besar error dalam pemodelan. Berdasarkan hasil yang diperoleh pada tabel diatas, nilai kedalaman dan perubahan volume dari sumber tekanan Gunung Merapi bervariasi tiap periode pengamatan. Perubahan volume yang dimaksud adalah suplai magma yang berasal dari dapur magma.

Dari hasil secara keseluruhan, sumber tekanan Gunung Merapi atau kantung magma berada pada kedalaman paling dangkal 2,042 $\mathrm{km}$ dan kedalaman paling besar adalah 4,533 $\mathrm{km}$ di bawah puncak kawah gunung. Sedangkan suplai magma sendiri cenderung variatif. Suplai magma terbesar adalah pada periode pengamatan 30 Nopember - 15 Desember 2017 dan perubahan volume terkecil adalah pada periode pengamatan 15-30 Nopember 2017. Ditinjau dari nilai error yang dihasilkan, error terbesar dihasilkan pada periode pengamatan 15-30 Nopember 2017. Estimasi error diperoleh dari nilai residual pada masing-masing stasiun terhadap model yang direpresentasikan dengan errorbar.

Aktivitas vulkanik gunungapi dipengaruhi oleh suplai pada kantong magma. Pada dasarnya magma terbentuk dari batuan yang meleleh akibat tekanan dan temperatur tinggi di dalam perut Bumi. Suplai magma berkaitan dengan sistem tektonik berupa subduksi yang disebabkan oleh tumbukan antara lempeng Indo-Australia dengan lempeng benua Asia. Tekanan dan temperatur yang tinggi dapat menyebabkan magma yang terbentuk dapat naik hingga terkumpul pada suatu reservoir yang disebut kantong magma. Naiknya magma disebabkan oleh batuan di sekitarnya yang sudah tidak mampu menahan tekanan akibat magma yang terus menerus terbentuk. Jumlah magma yang naik ke reservoir menyebabkan terjadinya perubahan volume pada reservoir atau kantong magma tersebut.

\section{KESIMPULAN}

Berdasarkan penelitian yang telah dilakukan, dapat diperoleh kesimpulan sebagai berikut:

1. Setelah dilakukan pemodelan tiap periode pengamatan, diperoleh hasil estimasi kedalaman sumber tekanan beserta perubahan volumenya berikut ini. 
- Pada periode pengamatan 1 - 16 September 2017, kedalaman sumber tekanan Gunung Merapi adalah $2579,282 \mathrm{~m}$ dan perubahan volumenya adalah sebesar $60913,918 \mathrm{~m}^{3}$.

- Pada periode pengamatan 16 September - 1 Oktober 2017, kedalaman sumber tekanan Gunung Merapi adalah $2042,450 \mathrm{~m}$ dan perubahan volumenya adalah sebesar $39403,980 \mathrm{~m}^{3}$.

- Pada periode pengamatan 16 - 31 Oktober 2017, kedalaman sumber tekanan Gunung Merapi adalah 3434,049 $\mathrm{m}$ dan perubahan volumenya adalah sebesar $50691,096 \mathrm{~m}^{3}$.

- Pada periode pengamatan 15 - 30 Nopember 2017, kedalaman sumber tekanan Gunung Merapi adalah $2456,148 \mathrm{~m}$ dan perubahan volumenya adalah sebesar $23075,386 \mathrm{~m}^{3}$.

- Pada periode pengamatan 30 Nopember - 15 Desember 2017, kedalaman sumber tekanan Gunung Merapi adalah 4533,337 $\mathrm{m}$ dan perubahan volumenya adalah sebesar $385147,190 \mathrm{~m}^{3}$.

- Pada periode pengamatan 15 - 30 Desember 2017, kedalaman sumber tekanan Gunung Merapi adalah $3583,457 \mathrm{~m}$ dan perubahan volumenya adalah sebesar $118784,829 \mathrm{~m}^{3}$.

Dari pemodelan yang telah dilakukan, Gunungapi Merapi tidak menunjukkan aktivitas yang signifikan.

2. Dari hasil tiap pemodelan, diperoleh nilai error tiap periode pengamatan sebagai berikut:

- Pada periode pengamatan 1 - 16 September 2017 diperoleh error sebesar $16,63 \%$.

- Pada periode pengamatan 16 September - 1 Oktober 2017 diperoleh error sebesar 35,61\%.
- Pada periode pengamatan 16 - 31 Oktober 2017 diperoleh error sebesar $26,89 \%$.

- Pada periode pengamatan 15 - 30 Nopember 2017 diperoleh error sebesar $37,36 \%$.

- Pada periode pengamatan 30 Nopember - 15 Desember 2017 diperoleh error sebesar 6,56\%.

- Pada periode pengamatan 15 - 30 Desember 2017 diperoleh error sebesar 21,27\%.

\section{DAFTAR PUSTAKA}

[1] H. Sirgurdsson, "Volcanology," University of Rhode Island, 2009

[2] A. Scarth, Volcanoes An Introduction. London: UCL Press, 1994.

[3] A. I. dkk Nandaka, "Pemantauan Gunungapi di Indonesia," Yogyakarta, 2009.

[4] D. Dzurisin, "Volcano Deformation Geodetic Monitoring Techniques," Springer, 2007.

[5] E. M. Anderson, "The Dynamics of The Formation of Cone-sheets, Ring-dykes, and Caldron Subsidence," in Proceedings of the Royal Society of Edinburgh, 1936, pp. 128-157.

[6] K. Mogi, "Relations between the Eruptions of Various Volcanoes and the Deformations of the Ground Surfaces around them," Bulletin of the Earthquake Research Institutes, 1958.

[7] D. F. McTigue, "Elastic Stress and Deformation Near A Finite Spherical Magma Body: Resolution of The Point Source Paradox," J. Geophys. Res., 1987.

[8] P. Segall, Earthquake and Volcano Deformation. Princeton University Press, 2010.

[9] R. et al. Carey, "Hawaiian Volcanoes From Source to Surface," 2015.

[10] R. I. Scarpa, R. \& Tilling, "Monitoring and Mitigation of Volcano Hazards," Springer, 1996.

[11] S. D. Ratdomopurbo A., Andreastuti, "Karakteristik Gunung Merapi," Yogyakarta, 2000 